\title{
TRANSMISSION RECEIVED
}

\author{
A difficultjourney.
}

\section{BY PETER J. ENYEART}

S uch journeys are permitted only for those who submit to death and rebirth. Eva remembered those words as they put her to sleep, as the bright round light overhead started to spin and then went out.

The company rep had said those words when Eva asked why she couldn't be shipped out to the asteroids in her original body. Oddly poetic for a corporate headhunter. She supposed he thought it sounded more momentous than saying: "It's not worth the time and expense to drag 60 kilograms of meat up out of the gravity well and across 30 vacuous light minutes when we can just radio the data necessary to reconstruct it on the other side."

"By providing your digital signature here," he had continued, "you affirm that you accept the Employment and Transmission Contract and understand its terms. We are required to remind you at this point that once the transmission and reconstitution of your data is complete, the original will be destroyed, in accordance with the law, which allows only one physical copy of a given individual to be in existence at any given time." When she'd hesitated, he'd smiled and put his hand on hers. "It doesn't hurt. You'll be put under anaesthesia before the recording is done. Then you'll just wake up at the other end. I've done it several times myself.' She'd resisted the urge to jerk away.

Eva had lost her lab as a result of false charges of academic dishonesty. Subsequent legal wrangling had exhausted her finances but yielded nothing. She was rejected from every remotely technical job she had applied for. Except one. Having nothing left to lose engenders boldness. She signed.

"The company will cover the costs of the basic transmission package, which guarantees a high enough resolution for you to perform your duties, but may entail amnesia, aphasia and partial paralysis, and an increased risk of neoplasia, fibromyalgia, aneurysm and osteoporosis, among other conditions."

"How can you guarantee I'll be able to do the work you need at the other end?"

"The prospective individual will be subjected to physical and psychological evaluations at the work site. Should the prospective individual not be up to spec, or should performance subsequently deteriorate, a replacement will be transmitted at no charge to you from the digital record of your molecular structure stored in our servers.

"There is also an upgrade to the highresolution package available for purchase. Actually, I am pleased to inform you that you have been pre-approved for a company loan that will cover the costs if you lack sufficient funds. The rate is very reasonable, and, conveniently, payments will be automatically deducted from your salary. Would you like to upgrade?"

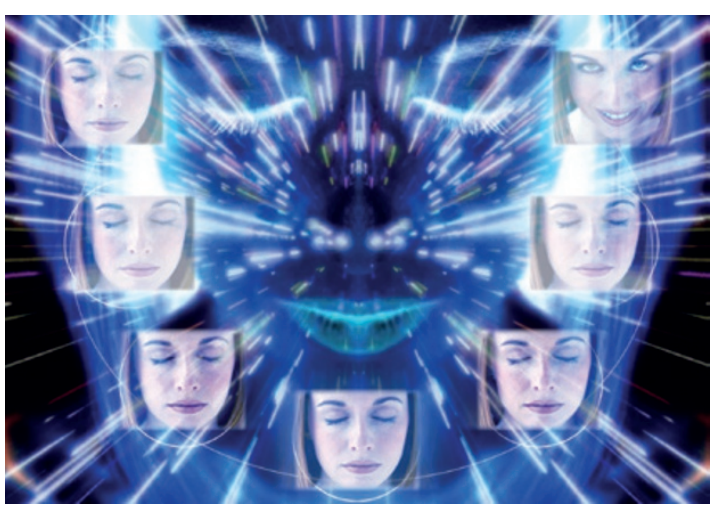

"Bastards!" she whispered, and opened her eyes.

The light above her was still bright but was now an oval. Her head was immobilized, and her wrists and ankles were strapped down. This was not in the contract.

"Congratulations, Eva," said a soft male voice. "You have escaped the cycles of linear death and rebirth." She looked around as best she could but couldn't see anyone. It smelled of bleach.

"What is it with you people and the cult talk?" she responded.

A face came into view. A young man. The bright backlight obscured his features. The voice she had heard before laughed, but didn't come from the man above her.

"Do you know where you are?" the man asked. It sounded like the first voice. Another face came into view, identical to the first.

"I damn well better be on 9 Metis, or I'll be suing for breach of contract."

The laugh again, off to the side.

"A version of you is on 9 Metis..."

A third version of the face now came into view. Realization hit her.

"You pirated me! Who the hell are you?"
"Clever and feisty. Yes, I'm glad we chose you."

"Who the hell are you?"

"Calm down." They seemed to take turns talking.

"You tell me where I am, and who you are, now!"

The faces gave each other concerned glances.

"We monitor the System Government's transmissions for individuals who have qualities we admire. When we find one, we make a copy."

Eva was intrigued. "How can you parse that information from the signal without physically reconstructing the whole person? That technology doesn't exist."

"It doesn't exist in the space controlled by the System Government. But the System is decadent. The desire to advance technology is gone, and anything startlingly new is seen as a threat to the status quo. You should know."

She scowled.

"We've been following your work for some time. We were very excited at the prospect of having you on our team."

"So what now?"

"Join us as we develop the technology to destroy the System Government and bring human civilization to the next phase of its development. Or be destroyed as an illegal copy."

"What choice do I have? I'm with you," she said, although her mind was already working on alternative arrangements.

"Excellent. Each of your copies will get a free back-up every six months, and - wait." The faces looked concerned. "Unfortunately, your neurological monitors are showing intense animosity. We'll have to try again with an approach better suited to building your confidence."

"No, wait! You can't _"

They smiled, and a hand patted hers. "It doesn't hurt. You'll be put under anaesthesia and then you'll just wake up again. It happens a few times to everyone until we learn how best to tailor our introduction to the new recruit." She tried to jerk away.

"Bastards!" she whispered, and opened her eyes.

Peter J. Enyeart is a graduate student working towards a PhD in cell and molecular biology at the University of Texas at Austin. He also enjoys sleeping and patent translation. 